Cerdeira, J. P. (2021). Trustworthiness, Security and the Decision to Buy on Electronic Platforms: Validity studies of a scale. Consumer Behavior Review, 5(1), 31-44.

ISSN: 2526-7884

Editor: Prof. Dr. Marconi Freitas da Costa

E-mail: cbr@ufpe.br
Evaluation: Double blind review

Received: August 18, 2020

Accepted: November 10, 2020

\title{
TRUSTWORTHINESS, SECURITY AND THE DECISION TO BUY ON ELECTRONIC PLATFORMS: VALIDITY STUDIES OF A SCALE
}

\author{
Confiabilidade, Segurança e a Decisão de Comprar em Plataformas Eletrônicas: Estudos de \\ validade de uma escala
}

\author{
José Pedro Cerdeira ${ }^{1}$ \\ ORCID: http://orcid.org/0000-0001-5487-6612 \\ E-mail: jpcerd@esec.pt
}

${ }^{1}$ Instituto Politécnico de Coimbra, Escola Superior Educação, Coimbra, Portugal

\begin{abstract}
The digitization of the economy is creating difficulties for traditional companies, jeopardizing the survival of the most resistant to change. With e-commerce platforms, small and micro-businesses can open new channels of communication with consumers, paying attention to some psychological factors that influence the decision to buy online: the perception of security, reputation, trust, appearance and design websites. The purpose of this article is to assess the importance of these factors in the decision to purchase online, using a questionnaire administered online (GoogleForms) to a Portuguese convenience sample $(n=163)$. The results reveal differences based on sex and consumers' previous experience in carrying out online transactions, as well as significant associations between some of the dimensions
\end{abstract}

\begin{abstract}
Resumo
A digitalização da economia está a criar dificuldades às empresas tradicionais, pondo em causa a sobrevivência das mais resistentes à mudança. Com as plataformas de comércio eletrónico, as pequenas e microempresas podem abrir novos canais de comunicação com os consumidores, devendo para o efeito prestar atenção a alguns fatores psicológicos que influenciam a decisão pela compra online: a perceção da segurança, reputação, confiança, aparência e design websites. 0 objetivo deste artigo é o de avaliar a importância destes fatores na decisão de compra on-line, através do recurso a um questionário administrado online (GoogleForms) a uma amostra de conveniência em Portugal $(n=163)$. Os resultados revelam diferenças em função do sexo e da experiência prévia dos
\end{abstract}


of the online trust scale of Sevim and Hall (2014) and the use of e-commerce platforms. In the conclusions, some proposals for conceptual clarification are presented and the psychometric properties of the scale used are discussed.

Keywords: E-commerce; Online trust; Websites trustworthiness; Security systems; B2C; Covid-19. consumidores na realização de transações online, assim como associações significativas entre algumas das dimensões da escala de confiança on-line de Sevim e Hall (2014) e a frequência do uso de plataformas de comércio eletrónico. Nas conclusões são apresentados ainda algumas propostas de clarificação conceptual e discutidas as propriedades psicométricas da escala usada.

Palavras-chave: Comércio eletrónico; Confiança online; Confiabilidade websites; Sistemas segurança; B2C; Covid-19.

\section{INTRODUCTION}

E-commerce platforms are a marketing tool for businesses to put their goods and services on the global market with relatively low investment. They are also a way for local micro-businesses to solve communication problems with potential consumers, and a good resource to explore new business opportunities. In economies dominated by small and micro-businesses, access to the digital market opens up a world of new possibilities and revenue streams unavailable in more conventional markets (Caboni \& Bruni, 2015; Pennington et al., 2003; Sila, 2019; Wirtz, 2019; WTO, 2013).

According to the Digital Economy Association (ACEPI, 2019), in 2018, Business to Consumer (B2C) e-commerce in Portugal amounted to around 5.5 billion Euros in just three service categories: accommodation (57\%), travelling (44\%) and entertainment (37\%), with customers or businesses from China (67\%), Spain (46\%), the United Kingdom (38\%), the United States (26\%), Germany (16\%) and Brazil (6\%), among others. Although the figures seem high, the truth is that they represent only $3 \%$ of national GDP, which is slightly below the EU average and falling short of the projections for the short and medium-term outlook for the European market (Eurostat, 2018, IDC, ACEPI \& Norte Digital, 2018).

However, alongside opportunities, there are also challenges. On part of the consumer, issues pertaining to fraud risk, privacy protection, security reliability systems, business reputation and organizational trust and trustworthiness, etc., tend to be identified by research as the most significant obstacles to the increase in online trade of goods and services (Bucher et al., 2014; Fang et al., 2014; Jones \& Leonard, 2014; Markou, 2019; Niemeier et al., 2013; Schultz \& Block, 2015; Reichelt et al., 2014).

Whereas for businesses - specifically businesses in Portugal -, the most relevant challenges relate to the skills required by e-commerce practices and digital transformation, which regard cybersecurity problems (78\%), cloud computing (74\%), big data \& analytics (60\%), among others, which, in turn, are associated to lack of suitable human resources (64\%) or lack of technological knowledge (36\%) to tap into the opportunities of globalised digital commerce (ACEPI, 2019).

In both cases, for consumers as well as for businesses, the assessment of objective security conditions in digital transactions and trust perception for the parties engaged in a commercial relationship are critical factors, having been identified by research as important drivers of the intention to purchase online (Chen et al., 2018; Faraoni et al., 2019; Stouthuysen et al., 2018; Tabari et al., 2017; Tavares et al., 2018; Turban et al., 2017; Thompson et al., 2019). For example, Hoffman et al. (1999) concluded that around $95 \%$ of website users refrained from providing requested personal data on one or more occasions and that $69 \%$ of those who refused to provide the data did so because the businesses failed to provide information on how said data would be used. Furthermore, even when businesses adopt encryption practices to ensure data confidentiality and security during a transaction (Secure Sockets Layer - SSL and Secure Electronic Transaction - SET), a part of potential customers 
refrain from using digital banking services (Luarn \& Lin, 2004), which suggests that the greatest problem does not lie in objective security conditions, but rather in subjective psychological factors (Amoroso \& Mukahi, 2013; Grabner-Krauter \& Bitter, 2015; Hsiao, 2009; Kim et al., 2008; Nguyen et al., 2018; Oliveira et al., 2017).

Therefore, the realisation of the potential opportunities presented by the digital economy depends on how small and micro-businesses are able to address some of the issues related to ecommerce trustworthiness and website reliability perception. Among these issues, the research highlights privacy protection (Joinson et al, 2010; Smith et al, 2011; Taddei \& Contena, 2013), fear of fraud (Guru et al., 2020; Moore et al., 2010; Soomro et al, 2020; Verbano \& Venturini, 2013), brand reputation (Feitosa \& Garcia, 2016; Ter Huurne et al, 2017), platform design and visual quality (Eckert et al., 2017; Geraldo \& Meinardes, 2017; Kim et al., 2010), etc.

This work aims at presenting some validity studies on the psychometric characteristics of a Portuguese version of an online trust scale by Sevim and Hall (2014) and, at the same time, also assess the importance of online trust expectations and website trustworthiness perceptions when deciding to purchase goods and services on e-commerce platforms, with a special focus on the variable associated to security perception.

\section{ONLINE TRUST EXPECTATION OR WEBSITE TRUSTWORTHINESS PERCEPTION?}

Trust is a complex concept, studied by several disciplines (Psychology, Sociology, Economy, Political Science, etc.), in different contexts (marketing, consumer behaviour, organisational behaviour, public relations, organisational communication, etc.) and with a variety of understandings regarding its nature (expectation, perception, value, attitude, mood, personality, etc.), therefore, there are countless theories on the phenomenon (Cook, 2001; Kramer \& Cook, 2004; Tyler \& Huo, 2002). However, despite this difficulty, there is also some consensus regarding what trust is or is not (Barney \& Hansen, 1994; Hardin, 2002).

First, there is a distinction between the concept of trust, understood as an expectation, and the concept of trustworthiness, understood as a perception. While trust refers to someone's decision to place himself or herself in a position vulnerable to the actions of another person or organisation, based on the belief that said position will result in a future benefit, trustworthiness refers to the subjective perception regarding the attributes the potential trustee may or not present and which justify the decision to run the risk of trusting (Mayer et al., 1995; Tomlinson et al, 2020). In other words, as a belief regarding the future attainment of a promising gain, trust can have a two-fold influence on the decision to run the risk of potential loss associated to a transaction and on the decision to waive surveillance efforts, for example, over e-commerce security systems.

To the extent that trust reduces uncertainty, when a consumer has high trust expectations towards an e-commerce platform, the likelihood of purchasing goods or services increases, which means that, from the point of view of the consumer, trust favourably influences decision-making, because it reduces risk perception regarding loss in an e-commerce transaction. On the other hand, as subjective assessment of the specific attributes of the potential trustee, the subjective assessment of the trustworthiness of the business tends to directly influence the decision to trust and, indirectly, the decision to complete electronic transactions. Although distinct, the two variables may interact in different ways to exert their influence on decision-making processes when it comes to purchasing goods and services online (Gefen, 2002).

Secondly, there are many factors that determine trustworthiness, in other words, perceptive factors preceding trust, which, depending on the trustee's context and nature, may undermine or strengthen trust. In the case of online trust, there are several attempts to identify and systematise those determining factors (Aiken et al., 2007; Amoroso \& Hunsinger, 2009; Kim \& Peterson, 2017; Varela et al., 2017; Wang \& Emurian, 2005), making it difficult to conduct an exhaustive inventory here. However, it is worth mentioning the importance that the perception of some specific factors can have in the decision to purchase online: the perception of the value of the loss risked, of security conditions, of the website design and visual, of the business or website reputation, of previous consumer experience, etc. 
Finally, there is a difference between the concept of trust expectation, as defined above and which results from a dynamic interaction between at least two parties engaged in a mutually influential relationship, and the concept of trust propensity, understood as a dispositional variable, more or less stable throughout time and cutting across more or less situations and contexts (Mayer et al., 1995; McCrae \& Costa, 1997; Rotter, 1980).

From this point of view, to understand the psychological processes of decision-making related to the online purchase of goods and services, it is useful to establish the difference between the concept of online trust expectation and, for example, the concept of website security perception. This differentiation is important because the intention of conducting online transactions may depend on positive expectations regarding the attainment of a gain (trust expectation), as well as on the subjective trustworthiness assessment regarding the different attributes of a specific e-commerce platform. The research conducted on these sets of variables tends to consider them orthogonal, since they independently compete to determine intention and behaviour (Aiken et al., 2007, Amoroso \& Hunsinger, 2009; Jones \& Leonard, 2014; Kim \& Peterson, 2017; Varela et al., 2017). This means that the decision to purchase may be influenced solely by trust expectations regarding a specific ecommerce platform, as well as by one or several website trustworthiness perceptions and, in particular, by security perceptions regarding the transaction system used for the purchase.

Therefore, given Sevim and Hall's theoretical framework (2014), the scale need not be an instrument to assess online trust expectation, but rather a scale to assess trust propensity and several dimensions of trustworthiness perception (understood as determining factors regarding the decision to trust an e-commerce platform), namely website security perception (one of the critical attributes of trustworthiness perception of an e-commerce platform).

In the following section, the scale used in this empirical study is presented, as well as Sevim and Hall's theoretical framework (2014) regarding online trust. Further ahead, the methodology, results and respective discussion will be presented, leading up to some conclusions drawn from the study, regarding both the scale's psychometric characteristics and theoretical implications.

\section{THE SCALE'S CONCEPTUAL FRAMEWORK}

The scale was developed by Sevim and Hall, aimed at "clarifying the impact of consumer trust on the intention to purchase online" (2014, p. 19), and consists of 21 items, organised in 4 dimensions. In providing the conceptual framework for the scale's assessment object, Sevim and Hall underline the ethical dimension of trust and highlight the importance of integrity and reliability perception of the counterparty engaged in the transaction, quoting the works of Morgan and Hunt (1994) to that end. They further quote Hosmer (1995), to associate the concept of trust to an ethical behaviour expectation based on the conviction that the counterparty will act properly and, therefore, make "decisions based on ethical principles" (Sevim \& Hall, 2014, p. 20).

Based on these elements, the authors argue about the role of trust as an instrument to remove the obstacles created by the feeling of insecurity in online transactions. In other words, they view online trust as a facilitator of e-commerce, since by decreasing uncertainty perception and fear of fraud it becomes a determining factor for the intention to conduct website-based transactions. To that end, the authors of the original study propose an instrument for the indirect assessment of online trust based on four dimensions: personal trust perception (4 items), website reputation (3 items), website visuality and design ( 3 items) and security systems (11 items). The answers are recorded in a fivepoint Likert scale, with labels reflecting different agreement or disagreement levels.

With a convenience sample, the authors collect data, conduct an exploratory factor analysis and put forward a factor solution with four factors, afterwards they conduct a regression and conclude that online trust has a significant impact on the intention to purchase online, although that varies according to each of the four dimensions considered for online trust: the impact is not significant for trust perception (itself) and is greater for the remaining three dimensions.

Given the set of theoretical questions laid out, as well as the empirical questions on the identification of psychological determinants in the intention to purchase on e-commerce platforms (online trust expectations, website trustworthiness perception, e-commerce security risk perception), 
there seems to be sufficient justification for the translation and adaptation, into Portuguese, of the scale, for the subsequent execution of an exploratory study on the psychometric properties of the online trust scale. In the study for the adaptation of the scale into Portuguese, the original dimensions were maintained, as well as the number of items associated to each dimension.

\section{METHOD}

\section{Participants}

The study was conducted in a convenience sample, consisting of 163 Portuguese subjects, 73 male (44.8\%) and 90 female (55.2\%), with a mean age of 29.06 years (SD $=10.14$ ), between 17 and 72 years old. The subjects were predominantly single (50.9\%), although a relevant percentage were married or in a non-marital partnership (44.8\%). Only 4.3\% were separated or divorced. Most of the subjects had a graduate degree (43.6\%), or had completed secondary education (32.5\%), some had Master's degrees (14.1\%) and others had only completed the third cycle of basic education (9.8\%). Regarding occupational status, 51 subjects were students (31.3\%), 17 were unemployed (10.4\%), 18 were working students $(11.1 \%)$ and 77 had a full-time occupation $(47.2 \%)$, as presented in Table 1. The active subjects had been working for a mean of 11.06 years ( $S D=10.34$ years), between a minimum of 1 year and a maximum of 48 years of professional experience. No questionnaires with incomplete answers or more than one answer were identified, therefore, all questionnaires were included in the sample.

Table 1

Demographic profile of respondents $(\mathrm{N}=163)$

\begin{tabular}{lcc}
\hline \multicolumn{1}{c}{ Variables } & $\mathbf{f}_{\mathbf{o}}$ & $\mathbf{\%}$ \\
\hline Gender & 73 & 44.8 \\
$\quad$ Male & 90 & 55.2 \\
$\quad$ Female & & \\
Marital status & 83 & 50.9 \\
$\quad$ Single & 73 & 44.8 \\
$\quad$ Married/Couple & 7 & 4.3 \\
$\quad$ Divorced/Separated & & \\
Education level & 16 & 9.8 \\
$\quad$ Basic education (9yrs) & 53 & 32.5 \\
$\quad$ Secondary education (12yrs) & 71 & 43.6 \\
$\quad$ Graduate school (1st degree) & 23 & 14.1 \\
$\quad$ Graduate school (2nd degree Master) & & \\
Occupational status & 51 & 31.3 \\
$\quad$ Student & 77 & 47.2 \\
$\quad$ Active professional & 18 & 11.1 \\
$\quad$ Working student & 17 & 10.4 \\
$\quad$ Unemployed/Retired & & \\
\hline Source: Data produced by the author (2020) &
\end{tabular}

\section{Instrument}

A questionnaire was used to collect the data. The first part consists of seven questions to characterise the sample as to marital status, gender, age, education, occupation and profession, and two questions to assess online purchasing behaviour (number of years purchasing online and number of online purchases in the last 30 days). The second part consists of the twenty-one items from Sevim and Hall's Online Trust Scale (2014). The answers to the items were encoded in a seven-point Likerttype scale, in which (1) was associated to "strongly disagree" and (7) to "strongly agree", slightly differing from the original scale, which used only five points. This change was introduced to increase answer variability. According to the original study, the scale has 4 dimensions: security systems (11 items), website reputation (3 items), trust perception (4 items) and website visuality and design (3 items). All the items are written in the affirmative, therefore, the dimensions are added, meaning a higher score corresponds to a higher expression of the latent variable assessed. 


\section{Procedures}

The twenty-one items of the scale were translated from English into Portuguese and subsequently translated back into English by another person, afterwards the semantic differences between the two versions were analysed and debated. The final result of the translation process was assessed by a group of 5 graduate students, in order to identify possible item understanding issues (Hill \& Hill, 2008), having some adjustments been made to the wording of a few items. Anticipating potential difficulties in obtaining a relevant number of answers from online consumers, the "snowball" technique was used to produce a convenience sample, from a group of 12 Master students, according to the suggestions from Goodman (1961) and Biernacki and Waldorf (1981). Through GoogleDocs, 163 valid answers were collected between April and June 2016. Afterwards, the data were input into and analysed with Statistical Package for Social Sciences (SPSS, version 21). The potential participants were informed of the study's objectives and the voluntary nature of their participation, while assured of the anonymity and confidentiality of the answers and data.

\section{Table 2}

Factor loadings using principal axis factoring method, with varimax rotation, communalities, eigenvalues and percentage of variance explained of online trust scale $(\mathrm{N}=163)$

\section{Portuguese item contente ${ }^{1}$}

3)Confio nas páginas web a partir das quais faço compras online.

5)Acho que fazer compras na internet é uma experiência segura.

4)Nos dias que correm, acho que é seguro fazer compras na internet e que já estamos legalmente protegidos.

2)Tenho a convicção que os meus dados pessoais e informações financeiras são protegidos pela página web que uso para fazer compras online.

1)Acho que a internet é suficientemente segura pelo que não preciso de me acautelar contra eventuais incidentes na realização de compras online.

11)Acho que muitas empresas dainternet têm uma imagem positiva junto do público. .45

10)Acho que as empresas que operam na internet fazem muito bem o seu trabalho. .44

9)As páginas web com a opção de vários sistemas de pagamento são mais fiáveis para mim.

16)Confio facilmente nas pessoas e nas instituições.

15)Tenho tendência para confiar fortemente nas pessoas e nas instituições.

17)Para mim não é difícil confiar numa pessoa ou numa instituição.

18)Confio nas pessoas e nas instituições mesmo quando tenho poucas informações sobre eles.

8)Acho que o uso de sistemas de segurança do tipo SSL e SET pelas empresas que operam na internet aumenta a confiança nelas.

7)Prefiro fazer compras em páginas web que usem sistemas de segurança do tipo SSL e SET.

6) Acho que os sistemas de segurança do tipo SSL e SET protegem adequadamente os consumidores quando fazem compras na internet.

13)Os comentários positivos deixados numa página web aumentam a minha confiança nessa página.

14)Os serviços de pós-venda fornecidos por uma página web aumentam a minha confiança nessa página.

12)Acho que as páginas da web certificadas são confiáveis.

21)As páginas web com um aspecto visual demasiado simples não me parecem confiáveis.

20)Se o aspecto visual de uma página $w e b$ for bom, então acho que a página é confiável.

19)0 aspecto visual da página web influencia a minha confiança na página.

Eigenvalue (after rotation)

$\%$ variance explained (after rotation)

Factor loading

\begin{tabular}{|c|c|c|c|c|c|}
\hline 1 & 2 & 3 & 4 & 5 & $\mathbf{h}^{2}$ \\
\hline .78 & .11 & .26 & .27 & .12 & .77 \\
\hline .77 & .28 & .24 & .25 & .11 & .79 \\
\hline .76 & .25 & .20 & .23 & & .74 \\
\hline .76 & .17 & .13 & & .15 & .64 \\
\hline .47 & .17 & .15 & & .21 & .32 \\
\hline .45 & & .36 & .29 & .18 & .45 \\
\hline .44 & .13 & .31 & .18 & .12 & .34 \\
\hline .43 & & .39 & .39 & .11 & .50 \\
\hline .19 & .90 & .13 & .16 & & .89 \\
\hline .15 & .76 & & .16 & & .64 \\
\hline .26 & .71 & & .10 & & .58 \\
\hline & .63 & & & .32 & .51 \\
\hline .30 & .12 & .86 & .20 & .16 & .90 \\
\hline .32 & & .81 & .11 & .17 & .82 \\
\hline .53 & .10 & .58 & .26 & & .70 \\
\hline .17 & & .10 & .84 & .12 & .77 \\
\hline .20 & .12 & .19 & .76 & .14 & .68 \\
\hline .36 & .17 & .26 & .52 & .12 & .52 \\
\hline .13 & & & & .84 & .72 \\
\hline .16 & .16 & .11 & .11 & .84 & .77 \\
\hline .19 & & .20 & .30 & .63 & .56 \\
\hline 4.02 & 2.63 & 2.50 & 2.32 & 2.16 & \\
\hline 19.1 & 12.5 & 11.9 & 11.1 & 10.3 & \\
\hline
\end{tabular}

Source: Data produced by the author (2020). 


\section{RESULTS}

To assess sample suitability for the exploratory factor analysis, the determinant of the interitem correlation matrix was calculated (0.0000003705), as well as the Kaiser-Meyer-Olkin index (KMO $=0.881)$ and Bartlett's Test of Sphericity $\left(x^{2}(210, N=163)=2282.954, p<.000\right)$. Overall, these indicators suggest the correlation matrix is different from an identity matrix, therefore, it can be subjected to an exploratory factor analysis. To explore possible factor orthogonality associated to online trust, the principal axis method was applied, based on the understanding that different item groups would assess conceptually distinct latent variables.

The solution extracted after the varimax rotation identified the existence of five orthogonal factors with eigenvalues higher than one, which cumulatively accounted for $64.5 \%$ of total variance. Specifically, the first factor accounted for $19.1 \%$ of total variance, aggregating the saturations of 9 out of the 11 items of the security systems dimension, with communalities between .32 and .79. The second factor (with a eigenvalue of 2.63 ) accounted for $12.5 \%$ of variance, aggregating the four items of the trust perception dimension. The third factor accounted for $11.9 \%$ of variance, aggregating the saturations of the 3 remaining items of the security systems dimension (items 6, 7 and 8, one of which also presented a saturation of .53 in the first factor - item 6). The content of these items pertains to the efficacy of Secure Sockets Layer (SSL) and Secure Electronic Transaction (SET) security systems. The remaining factors aggregate the saturations of the items of the respective dimensions (website reputation: $11.1 \%$ of variance; and website visuality and design: $10.3 \%$ of variance - items 19,20 and 21), as presented in Table 2.

Table 3 presents the descriptive statistics pertaining to the means and standard deviations of the totals of the five dimensions. Cronbach's alpha was used to assess the internal consistency of each of the measures. According to this method, alpha was .89 for the security systems dimension (consisting only of 9 out of the 11 original items), .91 for the remaining 3 items of the original security systems dimension (items 6, 7 and 8 for SET and SSL assessment), .83 for the 3 items of website reputation, and .86 and .85 for trust perception items ( 4 items) and website visuality and design items (3 items), respectively.

Table 3

Descriptive statistics, Cronbach's alpha and correlations between online trust scale dimensions ( $\mathrm{N}=163$ )

\begin{tabular}{|c|c|c|c|c|c|c|c|c|}
\hline & $\mathbf{M}$ & SD & alpha & 1 & 2 & 3 & 4 & 5 \\
\hline 1. Security systems total & 31.26 & 9.43 & .89 & - & & & & \\
\hline 2. SSL \& SET systems total & 12.36 & 3.43 & .91 & $.70^{*}$ & - & & & \\
\hline 3. Website's reputation total & 14.62 & 3.53 & .83 & $.58^{*}$ & $.50^{*}$ & - & & \\
\hline 4. Trust perception person total & 13.00 & 4.92 & .86 & $.43^{*}$ & $.29^{*}$ & $.31^{*}$ & - & \\
\hline 5. Website visuality and design total & 11.33 & 4.00 & .85 & $.42^{*}$ & $.36^{*}$ & $.36^{*}$ & $.26^{*}$ & - \\
\hline
\end{tabular}

$\mathrm{p}<.01$

Source: Data produced by the author (2020)

In the original study, the 11 items of the security systems dimension had an alpha of .92, while in this study the alpha obtained was .89 for 8 of the 11 security systems items, and .91 for the 3 remaining items for SSL and SET security perception (according to the exploratory factor analysis, the original factor was split into two factors).

Regarding the remaining dimensions, overall, the alpha obtained was very similar to the original study $(.79, .84$ and .76 , in the same order), therefore, according to Nunnally's criteria (1978) the values are deemed acceptable to assess the internal consistency of variable measures, since all values are higher than .70, which means item covariance within each dimension is relatively low. However, since when encoding answers in the Likert format the anchors were expanded from 5 to 7 , and three of the four scales presented a reduced number of items to measure the construct ( 3 or 4 items), complementary methods were used to assess the internal consistency of these measures. Therefore, for each of the scales, the removal of any of the items contributes to an alpha decrease, with mean inter-item correlation values of .77 for SSL \& SET assessment, .62 for website reputation, .60 for trust perception, and .65 for website visuality and design. 
The correlations between the totals of the four scales are all significant to $p<.01$, varying between a minimum of .26 and a maximum of .70, as presented in Table 3 , which suggests the five scales share significant, if relatively heterogeneous, variance portions, since they vary between $6.8 \%$ and $49.0 \%$. Consequently, trust perception assessment presents the lowest correlations with, on the one hand, website visuality and design assessment (.26) and, on the other hand, SSL and SET security systems assessment (.29), which suggests that, although the items present variances shared with the remainders, they also present their own specificities, which can justify the conceptualisation of a different dimension.

Table 4

Differences between means and standard deviations values on the scales according gender $(\mathrm{N}=163)$

\begin{tabular}{|c|c|c|c|c|c|c|}
\hline & \multicolumn{2}{|c|}{ Male } & \multicolumn{2}{|c|}{ Female } & \multirow{2}{*}{$\mathbf{T}$} & \multirow{2}{*}{$\mathbf{p}$} \\
\hline & $\mathbf{M}$ & SD & $\mathbf{M}$ & SD & & \\
\hline Security systems total & 34.99 & 9.67 & 28.23 & 8.10 & 4.765 & $.000^{*}$ \\
\hline SSL \& SET systems total & 13.70 & 3.41 & 11.27 & 3.08 & 4.793 & $.000^{*}$ \\
\hline Website's reputation total & 15.58 & 3.33 & 13.84 & 3.51 & 3.223 & $.002^{*}$ \\
\hline Trust perception person total & 13.40 & 5.12 & 12.68 & 4.77 & .920 & n.s. \\
\hline Website visuality and design total & 12.62 & 3.86 & 10.29 & 3.83 & 3.842 & $.000^{*}$ \\
\hline
\end{tabular}

n.s. $=$ The differences between the mean values are not statistically significant, $\mathrm{p}<.01$

Source: Data produced by the author (2020)

Table 4 presents the results pertaining to the assessment of the differences between mean values in the five scales, according to gender. Except for the trust perception scale, the differences determined by the $t$ student's test are statistically significant for $\mathrm{p}<.01$, with higher means for the male gender. With the ANOVA test no statistically significant differences were detected in the means pertaining to marital status, education and occupation.

\section{Table 5}

Differences between means and standard deviations values on the scales according prior e-commerce experience $(\mathrm{N}=163)$

\begin{tabular}{|c|c|c|c|c|c|c|}
\hline & \multicolumn{2}{|c|}{ Yes } & \multicolumn{2}{|c|}{ No } & \multirow{2}{*}{$\mathbf{T}$} & \multirow{2}{*}{$\mathbf{p}$} \\
\hline & $\mathbf{M}$ & SD & $\mathbf{M}$ & SD & & \\
\hline Security systems total & 34.62 & 7.91 & 20.21 & 3.99 & 10.797 & $.000^{* *}$ \\
\hline SSL \& SET systems total & 13.15 & 3.09 & 9.26 & 3.01 & 6.842 & $.000^{* *}$ \\
\hline Website's reputation total & 15.43 & 3.04 & 11.95 & 3.72 & 5.857 & $.002^{* *}$ \\
\hline Trust perception person total & 13.46 & 5.04 & 11.47 & 4.22 & 2.208 & $.029^{*}$ \\
\hline Website visuality and design total & 12.03 & 3.82 & 9.03 & 3.75 & 4.263 & $.000^{* *}$ \\
\hline
\end{tabular}

** $\mathrm{p}<.01,{ }^{*} \mathrm{p}<.05$

Source: Data produced by the author (2020)

However, using the same $t$ student's test to assess the statistical significance of the differences in total scale means and standard deviations according to e-commerce experience produces significant results for the five scales (Table 5), with higher means for those who have some prior experience with e-commerce. In other words, the consumers with experience in online transactions tend to assess more favourably security systems (including specifically SSL and SET), as well as website reputation, website visuality and design, and also tend to express higher trust perception. Online experience tends to generate more positive assessments in the five scale dimensions.

Finally, regarding the association between the different online trust scale measures and subject age, there is a statistically significant correlation only with the entirety of the security systems dimension, although negative and relatively weak $(\mathrm{r}=-.16, \mathrm{p}<.05)$, which suggests older consumers subjectively perceive e-commerce platforms as less safe, although cumulatively they tend to conduct a growing number of online purchases throughout the years $(r=.27, \mathrm{p}<.01)$, without said purchases amounting to significant frequency figures in the last 30 days, meaning, they simply accumulated 
transactions as years go by. Regarding e-commerce platform use behaviour, there are positive and statistically significant correlations between the number of years accumulated conducting transactions and the favourable assessment of security systems $(\mathrm{r}=.51, \mathrm{p}<.01)$, as well as with the remaining three of the four measures, although with more moderate correlation values. The exception pertains to website visuality and design, which has no significant correlation with the number of years.

Table 6

Values of Pearson's bivariate correlations between the totals of the scales, age and the two measures of behaviors for purchasing products and services online $(\mathrm{N}=163)$

\begin{tabular}{|c|c|c|c|c|c|c|c|c|}
\hline & 1 & 2 & 3 & 4 & 5 & 6 & 7 & 8 \\
\hline 1. Security systems total & - & & & & & & & \\
\hline 2. Website's reputation total & $.58^{* *}$ & - & & & & & & \\
\hline 3. Trust perception person total & $.43^{* *}$ & $.31^{* *}$ & - & & & & & \\
\hline 4. Website visuality and design total & $.42^{* *}$ & $.36^{* *}$ & $.26^{* *}$ & - & & & & \\
\hline 5. SSL \& SET systems total & $.64^{* *}$ & $.45^{* *}$ & $.26^{* *}$ & $.33^{* *}$ & - & & & \\
\hline 6. Age & $-.16^{*}$ & -.12 & .05 & -.13 & -.11 & - & & \\
\hline 7. № of years shopping online & $.51^{* *}$ & $.24^{* *}$ & $.21^{*}$ & .13 & $.18^{*}$ & $.27^{* *}$ & - & \\
\hline 8. № of online purchases in the last 30 days & $.31^{* *}$ & .15 & $.27^{* *}$ & -.06 & $.19^{*}$ & .16 & $.24^{* *}$ & - \\
\hline
\end{tabular}

The accumulated frequency of online purchases in the 30 days prior to data collection is positively and significantly associated to the security systems dimension $(r=.31, p<.01)$, the trust perception dimension $(\mathrm{r}=.27, \mathrm{p}<.01)$ and the SSL and SET dimension $(\mathrm{r}=.19, \mathrm{p}<.05)$. Overall, these results suggest that the consumers who purchased goods and services online recently are those who, on the one hand, are more trusting towards people and institutions, "even without much information" on them, and who, on the other hand, assess more favourably the security systems of e-commerce platforms, including data encryption systems (SSL) and data confidentiality and integrity systems, when using credit cards for electronic payments (SET). Regarding this last aspect, it should be highlighted that higher online purchasing frequency is associated to both an overall security perception and a specific security perception pertaining to SSL and SET. On the other hand, the results further suggest that higher online purchasing frequency is also associated to overall trust in people and institutions, "even without much information" on them.

Based on the figures in Table 6, it can also be said that consumers who have been using ecommerce platforms for more years tend to have conducted more online purchases recently $(\mathrm{r}=.24$, $\mathrm{p}<.01)$.

\section{DISCUSSION}

From the point of view of construct validity, the exploratory factor analysis of the 21 items of the online trust scale, through the principal axis method with varimax rotation, identified a fiveorthogonal-dimension solution, with some items presenting relevant saturations in more than one dimension. From the empirical point of view, three of the dimensions converge with the dimensions proposed by the scale's author and are conceptually reasonable, since they correspond to independent constructs, which are more or less well-defined in academic literature: website reputation (items 12, $13,14)$, trust perception (items 15, 16, 17, 18) and website visuality and design (items 19, 20, 21). This analysis is supported by the internal consistency measures of scale items, with Cronbach's alpha varying between .83 and .86, which can be deemed acceptable according to Nunnally's original criteria (1978), restated by Hair et al. (2019).

Regarding the two remaining dimensions found, there is divergence from the original study, pertaining essentially to items 6, 7 and 8 - which saturate in a dimension apart from that of the remaining security systems items. Overall, these three items assess consumer perception regarding the potential efficacy of two security systems for online data exchange (Secure Sockets Layer - SSL) and electronic payment through credit card (Secure Electronic Transaction - SET). Considering that 
these specific systems are not common knowledge for average website users, it makes sense that the answers given to the three items present saturations in a different factor from the one aggregating the remaining security perception items, therefore, in a future version of the scale these items may be eliminated or rewritten to explain their content. There were, in fact, clarification requests pertaining to this very aspect, during the reflection conducted in the scale's pre-test.

Given the $t$ student's test results regarding the differences between means and standards deviations according to gender, there were statistically significant differences for $\mathrm{p}<.01$ in four of the five measures. Except for trust perception, the remaining dimensions seem to have the potential to differentiate groups according to gender, with male subjects presenting higher means, which can be relevant to the scale's discriminating validity. Moreover, taking as criterion for mean comparison prior experience in online purchases, the $t$ student's test identified statistically significant differences between means and standards deviations for the five scales ( $\mathrm{p}<.05$ e $\mathrm{p}<.01$ ), always with prior ecommerce experience associated to higher means in the five scales.

Regarding criteria validity (Souza et al., 2017) for each of the five orthogonal dimensions of the scale, the website visuality and design dimension does not present any significant correlation with the two criteria used (number of years purchasing online and number of online purchases in the 30 days prior to data collection), which suggests some scale shortcoming, and the website reputation dimension presents significant correlation with one of the criterion, but not the other.

\section{FINAL CONSIDERATIONS}

This study aimed at, on the one hand, assessing the psychometric properties of a Portuguese version of Sevim and Hall's online trust scale (2014) in a Portuguese convenience sample, and, on the other hand, at identifying the importance of the different scale dimensions in the decision-making process regarding the purchase of goods and service on e-commerce platforms. According to the results obtained, the main study findings are thus presented.

Therefore, regarding the psychometric properties of the scale's adaptation, the study on construct validity led to a factor solution different from the one originally proposed by the scale's author. Rather than a structure consisting of four orthogonal factors, a five-factor structure was found, where one of the factors resulted from the splitting of the eleven items of the original security systems factor into two new factors, one with nine items, still called security systems, and another factor with three items, all assessing specific security systems like SSL and SET. The remaining scale items are organised in accordance with Sevim and Hall's study (2014). Besides these results pertaining to construct validity, overall, the remaining results can be considered acceptable, both regarding item internal consistency for each of the factors, and regarding correlations between the totals of factor assessment, as well as regarding the measures' ability to discriminate according to gender or the existence or not of prior e-commerce experience.

In a broader context, the results obtained allow for some more theoretical conclusions. First, for the purposes of conceptual clarification, it seems better to explicitly differentiate the concept of trust expectation from that of trustworthiness perception, and further differentiate both from the concept of dispositional trust, which is understood as a personality variable. There is a wide array of theoretical and empirical works that justify this conceptual differentiation, which gathers a certain consensus among the authors researching this area, therefore, there will be no need to elaborate on it, it will suffice to mention a few reference works, such as the works of Rotter (1980), Mayer et al. (1995) and Rousseau et al. (1998), who is even cited by Sevim and Hall (2014).

Secondly, and consequently, it seems preferable not to use trustworthiness perception or dispositional trust measures to assess trust expectation. In other words, if the objective of the online trust scale is to assess consumer expectations regarding whether the consumer is more or less convinced of being able to obtain the desired results from the online transaction, without having to resort to a monitoring system, then it does not make sense to use trustworthiness perception measures for that end ( 3 items for website reputation, 3 items for website visuality and design) nor dispositional trust ( 3 items for trust perception), because these measures assess a concept other than that of online trust. For example, item 12 - "I think that the recommended websites are trustworthy" - 
assesses website trustworthiness perception and not the website's reputation, let alone the online trust expectation of the potential consumer of online goods and services. Similarly, item 20 - "If a website's design is good, then I think the website is reliable" - also assesses a website attribute susceptible of generating a trustworthiness perception and does not reflect online trust expectation. Although the three concepts obviously present relationships (the correlations between the different scale dimensions are all significant), they do not reflect the same (conceptual) reality, nor should they be confused, under penalty of producing unnecessary misunderstanding.

The third conclusion drawn regards once again the exploratory factor analysis of the data obtained with the 21 items of the so-called online trust scale. Indeed, through the principal axis method and the varimax rotation, the solution that best explains the total variance of the results is a five-factor solution (relatively orthogonal between them), which reinforces the aforementioned theoretical conclusions. However, it is a solution that diverges from the one found by the scale's authors, since the factor saturations of the 11 items of the original security systems scale are divided into two orthogonal factors in the Portuguese sample, eight in one factor and the remaining three in another factor. Given the wording of these three items (6,7 and 8), it is clear they all pertain to specific security systems unknown to the sample (SET and SSL), which can explain this anachronism. This fact, although understandable, justifies the suggestion of removing these three items from the security systems dimension in future studies. However, to this end, it is necessary to clarify the conceptual understanding of security systems and conduct new validity studies.

Finally, one last general suggestion, but no less important: in studies of this nature, it is convenient to analyse more in-depth the relation between the topic's conceptual framework and the development of trust assessment instruments. Without this theoretical framework, empirical studies run the risk of becoming the target of two important criticisms expressed by Lewicki et al. (2006, p. 1014): a) "several studies use trust measures which are inconsistent with the definitions employed" to conduct the studies and b) "many trust scales provide little information on construct validity, hindering the assessment of its accurate grasp" of the nature of the phenomenon of trust.

Lastly, it is also worth mentioning this study's contribution to the identification of some variables associated to online purchasing frequency and to the number of years of experience with ecommerce platforms. Indeed, the data suggest that the two security perception assessment measures (overall security systems assessment and specific SSL and SET assessment) are significantly associated to higher frequency of online purchasing and a higher number of years accumulated purchasing on ecommerce platforms, in other words, the consumers who purchase the most and have been purchasing the longest favourably assess the security conditions of e-commerce platforms. This issue has gained added relevance since we are all living through a pandemic (covid-19), during which the access to e-commerce has become an essential tool to deal with the widespread imposed lockdown.

\section{References}

ACEPI (2019). Comércio electrónico chegou aos 87.5 mil milhões de euros em 2018. Disponível em: <https://www.acepi.pt/artigoDetalhe.php?idArtigo=92328>. Acess 16 Oct 2019.

Aikern, K., Mackoy, R., Liu, B., Fetter, R., \& Osland, G. (2007). Dimensions of internet commerce trust. Journal of Internet Commerce, 6(4), 1-25. doi: 10.1080/15332860802086136

Amoroso, D., \& Hunsinger, D. (2009). Analysis of the factors that influence online purchasing. Journal of Information Systems Research, 2(1), 1-16.

Amoroso, D., \& Mukahi, T. (2013). An examination of consumers' high and low trust as constructs for predicting online shopping behavior. Journal of Electronic Commerce in Organizations, 11(1), 117.

Barney, J., \& Hansen, M. (1994). Trustworthiness as a source of competitive advantage. Strategic Management Journal, 15, 175-190.

Biernacki, P., \& Waldorf, D. (1981). Snowball sampling: Problems and techniques of chain referral sampling. Sociological Methods \& Research, 10(2), 141-163. doi: 10.1177/004912418101000205 
Buscher, M., Liegl, M., \& Perng, S.-Y. (2014). Privacy, security, liberty: ICT in crises. International Journal of Information Systems for Crisis Response and Management, 6(4), 76-92.

Caboni, F., \& Bruni, R. (2015). On-line commerce and town center retailers' experience. International Journal of Marketing Studies, 7(6), 14-26.

Chen, C., Hsiao, K., \& Wu, S. (2018). Purchase intention in social commerce: An empirical examination of perceived value and social awareness, Library Hi Tech, 36(4), 583-604.

Cook, K. (Ed.). (2001). Trust in society. New York, N.Y.: Russell Sage Foundation.

Eckert, A., Dal Bó, G., Milan, G., \& Eberle, L. (2017). E-commerce: privacidade, segurança e qualidade das informações como preditores da confiança. Revista Pensamento Contemporâneo em Administração, 11(5), 49-69.

Eurostat (2018). Digital economy \& society in the EU. A browse through our online world in figures. Disponível em: <https://ec.europa.eu/eurostat/cache/infographs /ict/2018/index.html>. Acess 4 set 2019.

Fang, Y., Qureshi, I., Sun, H., McCole, P., Ramsey, E., \& Lim, K. (2014). Trust, satisfaction, and online repurchase intention: The moderating role of perceived effectiveness of e-commerce institutional mechanisms. MISQuarterly, 38(2), 407-427.

Faraoni, M., Rialti, R., Zollo, L., \& Pellicelli, A. (2019). Exploring e-loyalty antecedents in B2C ecommerce. British Food Journal, 121(2), 574-589.

Feitosa, D., \& Garcia, L. (2016). Sistemas de reputação: um estudo sobre confiança e reputação no comércio eletrônico brasileiro. Revista de Administração Contemporânea, 20(1), 84-105.

Gefen, D. (2002). Reflections on the dimensions of trust and trustworthiness among online consumers. ACM SIGMIS Database: the DATABASE for Advances in Information Systems, 33(3), 38-53.

Geraldo, G., \& Mainardes, E. (2017). Estudo sobre os fatores que afetam a intenção de compras online. REGE-Revista de Gestão, 24(2), 181-194.

Goodman, L. (1961). Snowball sampling. The Annals of Mathematical Statistics, 148-170. doi: 10.1214 /aoms/1177705148

Grabner-Kräuter, S., \& Bitter, S. (2015). Trust in online social networks: A multifaceted perspective, Forum for Social Economics, 44(1), 48-68.

Guru, S., Nenavani, J., Patel, V., \& Bhatt, N. (2020). Ranking of perceived risks in online shopping. Decision, 47(2), 137-152.

Hair, J. H., Gabriel, M. L., Silva, D., \& Junior, S. B. (2019). Development and validations of attitudes measurement scales: Fundamental and practical aspects. RAUSP Management Journal, 54(4), 490-507.

Hardin, R. (2002). Trust and trustworthiness. New York, NY: Russell Sage Foundation.

Hill, M., \& Hill, A. (2008). Investigação por questionário. Lisboa: Edições Sílabo.

Hoffman, D., Novak, T., \& Peralta, M. (1999). Building consumer trust online. How merchamts can win back lost consumer trust in the interests of e-commerce sales. Communications of the ACM, 42(4), 80-85

Hosmer, L. (1995). Trust: The connecting link between organizational theory and philosophical ethics. Academy of Management Review, 20, 379-403. doi: 10.2307/258851

Hsiao, M.-H. (2009). Shopping mode choice: Physical store shopping versus e-shopping. Transportation Research Part E, 86-95.

IDC, ACEPI \& Norte Digital (2018). Economia digital e o papel das PME da região norte. Principais economias na área do comércio eletrónico e de maior potencial de adesão aos produtos nacionais (TOP20). Disponível em: <https://www.nortedigital.pt/media/1066/ estudocompleto-estudo-norte-digital-acepi-top-20-de-economia-digital.pdf $>$. Acess 16 Oct 2019.

Joinson, A., Reips, U., Buchanan, T., \& Schofield, C. (2010). Privacy, trust, and self-disclosure online. Human-Computer Interaction, 25, 1-24.

Jones, K., \& Leonard, L. (2014). Factors influencing buyer's trust in consumer-to-consumer ecommmerce. Journal of Computer Information Systems, 54(4), 71-79.

Kim, D., Ferrin, D., \& Rao, H. (2008). A trust-based consumer decision-making model in electronic commerce: The role of trust, perceived risk, and their antecedents. Decision Support Systems, $44(2), 544-564$. 
Kim, J., Kim, W. \& Park, S. (2010). Consumer perceptions on web advertisements and motivation factors to purchase in the online shopping. Computers in Human Behavior, 26(5), 1028-1222

Kim, Y., \& Peterson, R. (2017). A meta-analysis of online trust relationships in E-commerce. Journal of Interactive Marketing, 38, 44-54. doi: 10.1016/j.intmar.2017.01.001

Kramer, R., \& Cook, K. (Eds.). (2004). Trust and distrust in organizations: Dilemmas and approaches. New York, NY: Russell Sage Foundation.

Lewicki, R., Tomlinson, E., \& Gillespie, N. (2006). Models of interpersonal trust development: Theoretical approaches, empirical evidence and future directions. Journal of Management, 32, 991-1022. doi: $10.1177 / 0149206306294405$

Luarn, P., Lin, H. (2004). Toward an understanding of the behavioral intention to use mobile banking. Computers in Human Behavior, 21, 873-891.

Markou, C. (2019). Consumer protection, online shopping platforms and EU law. New York: Taylor \& Francis.

Mayer, R., Davis, J., \& Schoorman, F. (1995). An integrative model of organizational trust. Academy of Management Review, 20, 709-734. doi: 10.2307/258792

McCrae, R., \& Costa, P. (1997). Personality trait structure as a human universal. American Psychologist, 52, 509-516. doi: 10.1037//0003-066X.52.5.509

Moore, T., Pym, D. J., \& Ioannidis, C. (Eds) (2010). Economics of information security and privacy. Berlin: Springer International Publishing.

Morgan, R., \& Hunt, S. (1994). The commitment-trust theory of relationship marketing. Journal of Marketing, 58, 20-38. doi: 10.2307/1252308

Nguyen, D., Leeuw, S., \& Dullaert, W. (2018). Consumer behavior and order fulfillment in online retailing: A systematic review. International Journal of Management Review, 20, 255-276.

Niemeier, S., Zocchi, A., \& Catena, M. (2013). Reshaping retail: Why technology is transforming the industry and how to win in the new consumer driven world. Cornwall, UK: John Wiley \& Sons.

Nunnally, J. (1978). Psychometric theory. New York, N.Y.: McGraw-Hill.

Oliveira, T., Alhinho, M., Rita, P., \& Dhillon, G. (2017). Modelling and testing consumer trust dimensions in e-commerce. Computers in Human Behavior, 71, 153-164.

Pennington, R., Wilcox, H., \& Grover, V. (2003). The role of system trust in business-to-consumer transactions. Journal of Management Information Systems, 20(3), 197-226.

Reichelt, J., Sievert, J., \& Jacob, F. (2014). How credibility cffects eWOM reading: The influences of expertise, trustworthiness, and similarity on utilitarian and social functions. Journal of Marketing Communications, 20(1-2), 65-81.

Rotter, J. (1980). Interpersonal trust, trustworthiness, and gullibility. American Psychologist, 35(1), 17. doi: 10.1037/0003-066X.35.1.1

Rousseau, D., Sitkin, S., Burt, R., \& Camerer, C. (1998). Not so different after all: A cross-discipline view of trust. Academy of Management Review, 23, 383-404. doi: 10.5465/AMR.1998.926617

Schultz, D., \& Block, M. (2015). US online shopping: Facts, fiction, hopes and dreams. Journal of Retailing and Consumer Services, 23, 99-106.

Sevim, N., \& Hall, E. (2014). Consumer trust impact on online shopping intent. Journal of Internet Applications and Management, 5(5), 19-28. doi: 10.5505/iuyd.2014.41636

Sila, I. (2019). Antecedents of electronic commerce in developing economies. Journal of Global Information Management, 27(1), 66-92.

Smith, H., Dinev, T., \& Xu, H. (2011). Information privacy research: An interdisciplinary review. MIS Quarterly, 35(4), 989-1015.

Soomro, Z., Shah, M., \& Ahmed, J. (2016). Information security management needs more holistic approach: A literature review. International Journal of Information Management, 36(2), 215-225.

Souza, A., Alexandre, N., \& Guirardello, E. (2017). Propriedades psicométricas na avaliação de instrumentos: Avaliação da confiabilidade e da validade. Epidemiologia e Serviços de Saúde, 26(3), 649-659.

Stouthuysen, K., Teunis, I., Reusen, E., \& Slabbinck, H. (2018). Initial trust and intentions to buy: The effect of vendor-specific guarantees, customer reviews and the role of online shopping experience. Electronic Commerce Research and Applications, 27, 23-38. 
Tabari, N., \& Abroud, E. (2017). Factors Affecting Customer's Tendency to Online Shopping. Journal of Economic \& Management Perspectives, 11(3), 549-556.

Taddei, S., \& Contena, B. (2013). Privacy, trust and control: Which relationships with online selfdisclosure? Computers in Human Behavior, 29(3), 821-826.

Tavares, J.M., Mishra, B., Kumar, R., Kahari, M., \& Zaman, N. (Ed) (2018). Handbook of e-business security. Boca Raton, FL, CRCPress/Taylor \& Francis Group.

Ter Huurne, M., Ronteltap, A., Corten, R., \& Buskens, V. (2017). Antecedents of trust in the sharing economy: A systematic review. Journal of Consumer Behaviour, 16(6), 485-498.

Thompson, F. M., Tuzovic, S., \& Braun, C. (2019). Trustmarks: Strategies for exploiting their full potential in e-commerce. Business Horizons, 62(2), 237-247.

Tomlinson, E. C., Schnackenberg, A. K., Dawley, D., \& Ash, S. R. (2020). Revisiting the trustworthinesstrust relationship: Exploring the differential predictors of cognition-and affect-based trust. Journal of Organizational Behavior, 41(6), 535-550.

Turban, E., Outland, J., King, D., Lee, J., Liang, T., \& Turban, D. (2017). Electronic commerce 2018: A managerial and social networks perspective. Berlin, Springer International Publishing.

Tyler, T., \& Huo, Y. (2002). Trust in the law. Encouraging public cooperation with the police and courts. New York, NY: Russell Sage Foundation.

Varela, M., Araújo, A., Vieira, G., Manupati, V., \& Manoj, K. (2017). Integrated framework based on critical factors for E-commerce. Journal of Information Systems Engineering \& Management, 2(1), 1-9. doi: $10.20897 /$ jisem.20170

Verbano, C., \& Venturini, K. (2013). Managing risks in SMEs: A literature review and research agenda. Journal of Technology Management \& Innovation, 8(3), 186-197.

Wang, Y., \& Emurian, H. (2005). An overview of online trust: Concepts, elements and implications. Computers in Human Behavior, 21(1), 105-125. doi: 10.1016/j.chb.2003.11.008

Wirtz, B. (2019). Digital business models. Berlin, Springer International Publishing.

World Trade Organization - WTO (2013). E-commerce in developing countries: Opportunities and challenges for small and medium-sized enterprises. Disponível em: <https://www.wto.org/english/res_e/booksp_e/ecom_brochure_e.pdf> Acess 16 Jun 2020.

\section{Appendix}

${ }^{1}$ Below are the original items of the Online trust scale (Sevim \& Hall, 2014):

1) I think that the Internet is safe enough and I do not have any reservations incident to shopping.

2) I believe that my personal and financial information are protected by the website from which I make shopping.

3) I trust the websites from which I make shopping.

4) I think that in our day, Internet shopping is safe enough and legally protected.

5) I think that Internet shopping is a safe experience.

6. I think that security systems such as SSL and SET, protects the consumers shopping via Internet adequately.

7) I prefer shopping from the websites that use security systems such as SSL and SET.

8) I think that use of security systems such as SSL and SET by businesses operating via Internet increase trust in them.

9) Websites with various payment options are more reliable for me.

10) I think that the businesses operating via Internet do this work really well.

11) I think that many Internet businesses have a positive image in the public.

12) I think that the recommended websites are trustworthy.

13) The positive reviews I hear about a website increases my trust in that website.

14) After-sales services provided by a website increase my trust in that website.

15) I'm inclined highly to trust a person or an institution

16) It is easy for me to trust a person or an institution.

17) It is not hard to trust a person or an institution.

18) I trust a person or an institution even if I have very little information about them.

19) The visual features of a website affect my trust on that website.

20) If a website's design is good, I think the website is reliable.

21) Websites with simple designs do not look reliable to me. 